Check for updates

Cite this: RSC Adv., 2019, 9, 11737

Received 12th February 2019

Accepted 8th April 2019

DOI: 10.1039/c9ra01107b

rsc.li/rsc-advances

\title{
Development of moisture-proof polydimethylsiloxane/aluminum oxide film and stability improvement of perovskite solar cells using the film $\uparrow$
}

\author{
Eun Young Choi, ${ }^{a}$ Ju-Hee Kim, ${ }^{a}$ Bu-Jong Kim, ${ }^{a}$ Ji Hun Jang, ${ }^{a}$ Jincheol Kim*ab \\ and Nochang Park (D)*a
}

\begin{abstract}
A method for enhancing the moisture barrier property of polydimethylsiloxane (PDMS) polymer films is proposed. This is achieved by filling the PDMS free volume with aluminum oxide $\left(\mathrm{AlO}_{x}\right)$. To deposit $A l O_{x}$ inside PDMS, thermal atomic layer deposition (ALD) is employed. The PDMS/AlO film thus produced has a $30 \mathrm{~nm} \mathrm{AlO}$ layer on the surface. Its water vapor transmission rate (WVTR) is $5.1 \times 10^{-3} \mathrm{~g} \mathrm{~m}^{-2} \mathrm{~d}^{-1}$ at $45{ }^{\circ} \mathrm{C}$ and $65 \%$ relative humidity $(\mathrm{RH})$. The activation energy of permeability with the $\mathrm{PDMS}^{\mathrm{A}} \mathrm{AlO} \mathrm{O}_{x}$ film for moisture permeation is determined to be $35.5 \mathrm{~kJ} \mathrm{~mol}^{-1}$. To investigate the moisture barrier capability of the $\mathrm{PDMS} / \mathrm{AlO}_{x}$ layer, $\left(\mathrm{FAPb}_{3}\right)_{0.85}\left(\mathrm{MAPbBr}_{3}\right)_{0.15} /$ spiro-OMeTAD/Au perovskite solar cells are fabricated, and encapsulated by the $\mathrm{PDMS} / \mathrm{AlO}_{x}$ film. To minimize the thermal damage to solar cells during ALD, $\mathrm{AlO}_{x}$ deposition is performed at $95{ }^{\circ} \mathrm{C}$. The solar cells exposed to $45{ }^{\circ} \mathrm{C}-65 \% \mathrm{RH}$ for $300 \mathrm{~h}$ demonstrate less than a $5 \%$ drop in the power-conversion efficiency.
\end{abstract}

\section{Introduction}

Recently, solar cell encapsulation employing organic-inorganic halide perovskite solar cells (PSCs) to overcome instability in the presence of moisture has gained considerable attention..$^{\mathbf{1 - 4}}$ Recently, various methods, such as using UV curable epoxy ${ }^{5}$ and moisture barrier film ${ }^{3,6}$ to protect the PSCs from moisture have been proposed, which show encouraging results under high humidity. ${ }^{7-11}$ The previous studies reported that encapsulated PSCs using an organic layer start degrading from perovskite decomposition when moisture penetrates the organic layer.,12-14 To overcome this, atomic layer deposition (ALD) is used as one of the effective techniques to fabricate oxide thin films on the device. Furthermore, researchers reported the results of the water vapor transmission rate (WVTR) of oxide films fabricated by ALD. Wang et al. reported the use of ALD to fabricate $\mathrm{Al}_{2} \mathrm{O}_{3} / \mathrm{MgO}$, which when coupled with solutionprocessed polymer, achieved a high moisture barrier and has a superior WVTR of $1.05 \times 10^{-6} \mathrm{~g} \mathrm{~m}^{-2} \mathrm{~d}^{-1}$ at $60{ }^{\circ} \mathrm{C}-100 \% \mathrm{RH} .{ }^{15}$ Nam et al. obtained a WVTR of $2 \times 10^{-3} \mathrm{~g} \mathrm{~m}^{-2} \mathrm{~d}^{-1}$ at $85{ }^{\circ} \mathrm{C}-85 \%$ $\mathrm{RH}$ using a composite layer of $\mathrm{ALD} \mathrm{Al}_{2} \mathrm{O}_{3}$ and chemical-vapor-

${ }^{a}$ Electronic Convergence Material \& Device Research Center, Korea Electronics Technology Institute, Seong-Nam, Republic of Korea. E-mail: ncpark@keti.re.kr; jckim@keti.re.kr; Tel: +82-31-789-7057

${ }^{b}$ Australian Centre for Advanced Photovoltaics (ACAP), School of Photovoltaic and Renewable Energy Engineering, University of New South Wales, Sydney 2052, Australia $\dagger$ Electronic supplementary information (ESI) available. See DOI: 10.1039/c9ra01107b deposited graphene. ${ }^{16}$ We achieved a WVTR of $1.84 \times 10^{-2} \mathrm{~g}$ $\mathrm{m}^{-2} \mathrm{~d}^{-1}$ at $45{ }^{\circ} \mathrm{C}-100 \% \mathrm{RH}$ when thermal ALD is used. ${ }^{17}$ Based on our previous research, ${ }^{17}$ a low process temperature of ALD and a method to enhance the WVTR are required to be used in PSCs. For low damage of PSCs during ALD, we performed ALD at a temperature as low as $95{ }^{\circ} \mathrm{C}$. However, we observed that it is difficult to achieve the high moisture barrier property with a single $\mathrm{Al}_{2} \mathrm{O}_{3}$ film. Therefore, previous researchers employed organic materials to enhance the moisture barrier property. Park et al. introduced the thin film encapsulation method for OLED devices by coating polydimethylsiloxane (PDMS) on metal foil. They reported a WVTR of $4.4 \times 10^{-4} \mathrm{~g} \mathrm{~m}^{-2} \mathrm{~d}^{-1}$ at $45{ }^{\circ} \mathrm{C}$ $40 \%$ RH. ${ }^{18}$ Similarly, Hong et al. introduced flexible lamination encapsulation using graphene films with PDMS on polyethylene terephthalate (PET). ${ }^{19}$ Liu et al. developed a hole transport material (HTM)-free PSC by using a carbon electrode and performing PDMS encapsulation. They reported long-term stability of PSCs in low-humidity conditions at room temperature for 3000 h. $^{20}$ We summarized the related works in Table S1. $\dagger$ However, those results lacked the investigation of how the WVTR was increased using an organic layer. Therefore, first, we focused on a method to improve the moisture barrier property by combining PDMS and $\mathrm{AlO}_{x}$. Second, we investigated why the WVTR is enhanced when the PDMS/AlO ${ }_{x}$ double layer is used. PDMS is employed because of its low cost, ${ }^{21}$ chemical stability, ${ }^{22}$ easy process to fabricate film or mold ${ }^{23}$ high transparency, ${ }^{24}$ and common usage in the microfluidic cell $^{25-27}$ and other devices. ${ }^{28,29}$ In addition, it exhibits the hydrophobic property. ${ }^{30}$ 
However, these results lack the investigation of how the WVTR was increased using an organic layer.

The objectives of the research reported in this study are: (1) to develop a method of enhancing the moisture barrier property of the PDMS by employing $\mathrm{AlO}_{x}$ thin film; (2) to determine the WVTR of the PDMS/AlO ${ }_{x}$ film by the Ca corrosion test, and to investigate the mechanism that improves the WVTR; (3) and to investigate the stability of PSCs encapsulated by the PDMS/AlO moisture barrier film. Accordingly, we fabricated three types of films: (a) $\mathrm{AlO}_{x}$, (b) $\mathrm{AlO}_{x} / \mathrm{PDMS}$, and $\mathrm{PDMS}_{\mathrm{AlO}}$ (Fig. S1 $\dagger$ ). To examine the effectiveness of the moisture barrier film, we encapsulated the perovskite solar cell, $\left(\mathrm{FAPbI}_{3}\right)_{0.85}\left(\mathrm{MAPbBr}_{3}\right)_{0.15} /$ spiro-OMeTAD/Au, by these films.

\section{Results and discussion}

Effect of TMA and water pulse time on the deposition rate of $\mathrm{AlO}_{x}$ thin film

We investigated if TMA and water pulse times affect the growth rate of the $\mathrm{AlO}_{x}$ film. Fig. 1a shows that the growth rate per cycle (GPC) of the $\mathrm{AlO}_{x}$ film is in the 1.20-1.38 $\AA$ range with the change in TMA pulse time from $0.5 \mathrm{~s}$ to $3.0 \mathrm{~s}$. Further, we examined the effect of water pulse time on the GPC of the $\mathrm{AlO}_{x}$ film.

Fig. $2 \mathrm{~b}$ shows that the GPC of the $\mathrm{AlO}_{x}$ film doubled in $3 \mathrm{~s}$ water pulse time as compared to that obtained with $0.5 \mathrm{~s}$ water pulse time. This is attributed to precursor decomposition. ${ }^{31}$ Based on these results, we determined the GPC in accordance with the number of ALD cycles. Fig. 2a illustrates that the slope is $1.09 \AA$ per cycle, which means the $\mathrm{AlO}_{x}$ film grows linearly in a positive relationship with the ALD cycles. To examine the thickness, we employed transmission electron microscopy (TEM) and energy dispersive spectroscopy (EDS) analysis after 200 cycles (Fig. 2b and c). These figures indicate that the $\mathrm{AlO}_{x}$ films formed uniformly on the substrate and consisted of $\mathrm{Al}$ and O. The presence of oxygen in the substrate is attributed to oxidation. ${ }^{32}$ Therefore, we observed that the thickness of $\mathrm{AlO}_{x}$ films could be determined by changing the ALD cycles at fixed TMA and water pulse times.
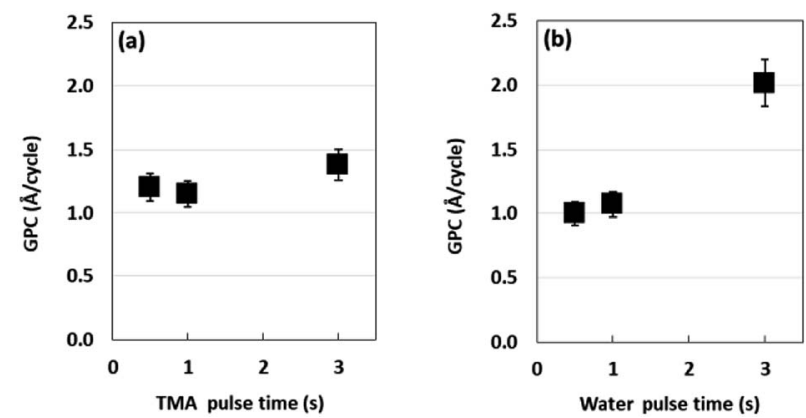

Fig. 1 Effect of (a) TMA pulse time and (b) water pulse time on the growth rate of $\mathrm{AlO}_{x}$ thin films. Si wafer substrates were used to form the $\mathrm{AlO}_{x}$ thin film. The ALD process was performed at $95{ }^{\circ} \mathrm{C}$ for 100 cycles.
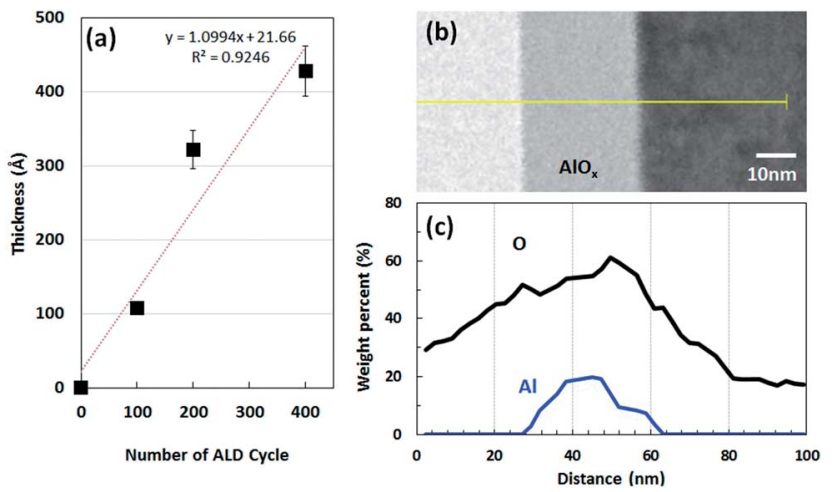

Fig. 2 (a) Thickness of $\mathrm{AlO}_{x}$ thin films as a function of number of ALD cycles. (b) TEM image of $30 \mathrm{~nm} \mathrm{AlO}_{x}$ layer that is formed by using condition $C$ in Table 1. (c) EDS element line scan results of the yellow line in (b).

Once the $\mathrm{AlO}_{x}$ thin films were formed by ALD process, we used an X-ray photoelectron spectra (XPS) to ensure the stoichiometric ratio of $\mathrm{Al}$ and $\mathrm{O}$. Correlation factors $\left(R^{2}\right)$ of devolution fitting in Fig. 3(a) and (b) were 0.995, 0.999, respectively. Fig. 3a shows the $\mathrm{Al} 2 \mathrm{p}$ spectra of $\mathrm{AlO}_{x}$ with Gaussian fitting. It is distributed by one component at the $74.45 \mathrm{eV}$, which corresponds to $\mathrm{Al}-\mathrm{O} .{ }^{32} \mathrm{Fig}$. $3 \mathrm{~b}$ shows that the $\mathrm{O}$ 1s spectra of $\mathrm{AlO}_{x}$ consist of two peaks, which correspond to $\mathrm{Al}-\mathrm{O}$ and $\mathrm{Al}-\mathrm{OH}$ bonds at $531.29 \mathrm{eV}$ and $532.60 \mathrm{eV}$, respectively. ${ }^{33}$ On the base of peak devolution of each element, we determined the stoichiometric ratio of the fabricated film by ALD. We chose the peak area of $\mathrm{Al}-\mathrm{O}$ bonding from the devolved $\mathrm{Al} 2 \mathrm{p}$ and $\mathrm{O} 1$ s spectra, and used the element-specific cross sections of $\mathrm{Al} 2 \mathrm{p}$ and $\mathrm{O}$ $1 \mathrm{~s} .{ }^{33,34}$ The results demonstrated that the stoichiometric ratio of [O/Al] was 1.38 (Table S3†)

\section{PDMS film filled with $\mathrm{AlO}_{x}$ and its WVTR}

Based on our previous study and other research findings, ${ }^{35-38}$ the $\mathrm{AlO}_{x}$ thin film requires other layers for enhancing the moisture barrier property. For this experiment, we used PDMS as the organic layer. To cure a PDMS layer, it was heated at $95{ }^{\circ} \mathrm{C}$ for $1 \mathrm{~h}$ after spinning coating. This temperature corresponds to the temperature of ALD process. This allowed the PDMS to be cured further in the ALD chamber. The subsequent step was to deposit $\mathrm{AlO}_{x}$. After the formation of each layer, we examined the quality of the layer, especially the WVTR and contact angle.
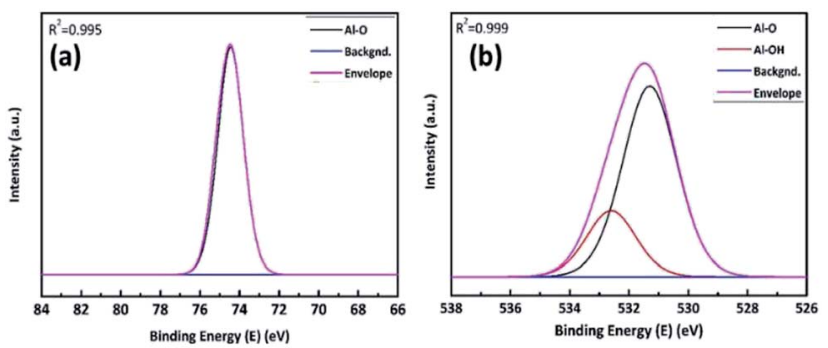

Fig. 3 XPS spectra of $\mathrm{AlO}_{x}$ thin films on Si wafer. (a) Al 2p and (b) O 1s. 
First, we investigated the effect of filling $\mathrm{AlO}_{x}$ with free volume in PDMS on the WVTR. Fig. 4 show that the lag time of the $\mathrm{Ca} /$ $\mathrm{PDMS} / \mathrm{AlO}_{x}$ film was approximately twice as that of $\mathrm{Ca} / \mathrm{AlO}_{x} /$ PDMS, which are measured to be $19.71 \mathrm{~h}$ and $8.01 \mathrm{~h}$, respectively. The WVTR values of the $\mathrm{PDMS} / \mathrm{AlO}_{x}$ and $\mathrm{AlO}_{x} / \mathrm{PDMS}$ film are determined to be $5.10 \times 10^{-3} \mathrm{~g} \mathrm{~m}^{-2} \mathrm{~d}^{-1}$ and $1.46 \times 10^{-2} \mathrm{~g} \mathrm{~m}^{-2}$ $\mathrm{d}^{-1}$, respectively (refer Table 1). The WVTR value of a $30 \mathrm{~nm} \mathrm{AlO}_{x}$ film was determined to be $2.89 \times 10^{-2} \mathrm{~g} \mathrm{~m}^{-2} \mathrm{~d}^{-1}$, which is in good agreement with $1.84 \times 10^{-2} \mathrm{~g} \mathrm{~m}^{-2} \mathrm{~d}^{-1}$ (what we had done with AQUATRON model 2 (Mocon) before). ${ }^{17}$ Interestingly, the WVTR value was decreased by orders of $10^{-1}$ when we performed $\mathrm{AlO}_{x}$ deposition on the PDMS layer. To examine the reason of enhancing the moisture barrier property, we employed TEM/EDS, ToF-SIMS, and XPS. First, we will explain the TEM results and then discuss the ToF-SIMS and XPS results.

For the Si/AlO ${ }_{x} / \mathrm{PDMS}$ sample (Fig. 5a), EDS mapping results showed clear distinctions in the $\mathrm{AlO}_{x}$ and the PDMS layers. Moreover, for the Si/PDMS/AlO ${ }_{x}$ sample (Fig. 5b), Al was detected in the PDMS layer. We employed TOF-SIMS to analyze the elements inside the PDMS layer more precisely. Fig. 6 shows that $\mathrm{Al}$ exists from the surface to several hundred nanometers. To make sure that $\mathrm{Al}$ exists in the PDMS layer, we performed XPS analysis. Fig. 7a and b can be devaluated with Gaussian fitting whose correlation factors were 0.999 and 0.996 each. Fig. 7a illustrates the binding energy of $\mathrm{Al} 2 \mathrm{p}$ of the $\mathrm{PDMS} / \mathrm{AlO}_{x}$ film. The spectra was obtained at $74.45 \mathrm{eV}$ and $75.2 \mathrm{eV}$, which represents $\mathrm{Al}-\mathrm{O}$ and $\mathrm{Al}-\mathrm{OH}$ bonds, respectively. ${ }^{32}$ Interestingly, unlike the $\mathrm{Al}$ 2p peak of $\mathrm{AlO}_{x}$ reference, the peak area of the $\mathrm{Al}-\mathrm{OH}$ bond for PDMS $/ \mathrm{AlO}_{x}$ occupies in the total $2 \mathrm{p}$ peak. The diffusivity and miscibility of the ALD precursor is related to the free volume of polymer, ${ }^{39}$ reactive site of polymer, ${ }^{40}$ and polymer porosity and crystallinity. ${ }^{\mathbf{4 1 , 4 2}}$ These results are affected by the intrinsic property of the PDMS such as its crystallinity and reactivity ${ }^{\mathbf{4 3}}$ and are similar to those of polyethylene ethoxylate (PEIE), whose semicrystalline nature affects the retarded nucleation of the ALD layer. ${ }^{44}$ Fig. $7 \mathrm{~b}$ shows the $\mathrm{O} 1 \mathrm{~s}$ spectra of the $\mathrm{PDMS} / \mathrm{AlO}_{x}$ film. The $\mathrm{Al}-\mathrm{O}$ spectra and $\mathrm{Al}-\mathrm{OH}$ were detected at $531.29 \mathrm{eV}$ and $532.60 \mathrm{eV}$, which are from the $\mathrm{AlO}_{x}$ layer. As shown in Fig. $\mathrm{S} 4, \dagger$ the peak related to $\mathrm{AlO}_{x}$ layer, where the peak between $3400 \mathrm{~cm}^{-1}$ and $3000 \mathrm{~cm}^{-1}$ were attributed to stretching vibrations of $\mathrm{Al}-$

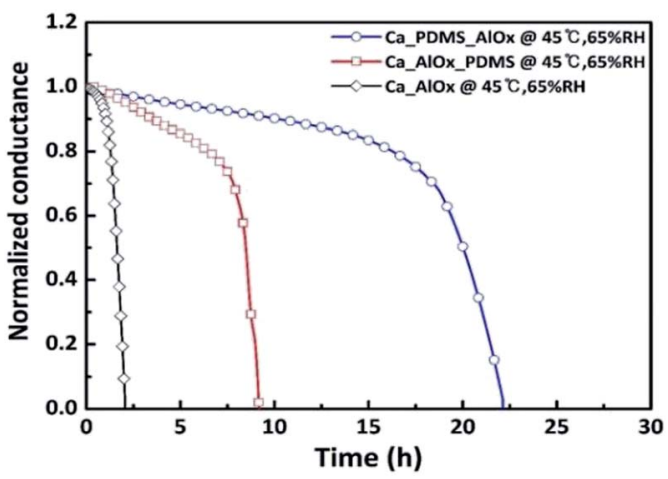

Fig. 4 Ca conductance test encapsulated by three types of materials: $\mathrm{AlO}_{x}, \mathrm{PDMS} / \mathrm{AlO}_{x}$, and $\mathrm{AlO}$ / PDMS. This test was conducted at $45^{\circ} \mathrm{C}$ and $65 \% \mathrm{RH}$.
Table 1 Calculated WVTR and lag time of $\mathrm{AlO}_{x}, \mathrm{AlO}_{x} / \mathrm{PDMS}$, and $\mathrm{PDMS} / \mathrm{AlO}_{x}$ at $45^{\circ} \mathrm{C}$ and $65 \% \mathrm{RH}$

\begin{tabular}{llr}
\hline Sample & WVTR $\left(\mathrm{g} \mathrm{m}^{-2} \mathrm{~d}^{-1}\right)$ & \multicolumn{1}{l}{$\begin{array}{l}\text { Lag time } \\
(\mathrm{h})\end{array}$} \\
\hline $\mathrm{AlO}_{x}$ & $2.89 \times 10^{-2}$ & 0.86 \\
$\mathrm{AlO}_{x} / \mathrm{PDMS}^{-2}$ & $1.46 \times 10^{-2}$ & 8.01 \\
$\mathrm{PDMS}_{\mathrm{AlO}}$ & $5.10 \times 10^{-3}$ & 19.71
\end{tabular}

$\mathrm{OH}^{45}$ and the peak of $1000 \mathrm{~cm}^{-1}$ was corresponded to $\mathrm{Al}-\mathrm{O}$ stretching vibrations. ${ }^{46}$ The other spectra peak of $533.0 \mathrm{eV}$ represent the binding energies of $\mathrm{O}-\mathrm{Si}-\mathrm{O} .{ }^{47}$ These spectra peaks is from the PDMS layer supported by results from FTIR (Fig. S4 $\dagger$ ), which shows the peak at $1090 \mathrm{~cm}^{-1}$ were attributed to $\mathrm{Si}-\mathrm{O}-\mathrm{Si}$ stretching vibration in PDMS bone structure. ${ }^{48} \mathrm{An} \mathrm{AlO}_{x}$ cluster forms in the void inside the PDMS layer during ALD process. $^{39,44,49,50}$ Therefore, our results demonstrated that the moisture barrier property of the PDMS/AlO ${ }_{x}$ film was improved by filling the free volume in PDMS layer with $\mathrm{AlO}_{x}$.

Second, we investigated the effect of $\mathrm{AlO}_{x}$ and PDMS on surface properties, such as contact angle and surface tension. ${ }^{51}$ The permeation of water molecules is related to the wettability of the barrier thin film. Fig. 8 shows that the hydrophobicity was improved by forming the PDMS layer on the $\mathrm{AlO}_{x}$ thin film. The contact angle and surface tension of the $\mathrm{AlO}_{x} / \mathrm{PDMS}$ sample was determined to be $86.8^{\circ}$ and $30.0 \mathrm{mN} \mathrm{m}^{-1}$, respectively (refer Table 2). These results are attributed to the chemical structure of PDMS, which have the methyl functional group. ${ }^{52}$ Interestingly, the contact angle of $\mathrm{AlO}_{x}$ increased from 60.8 to 74.1 when PDMS was used in the lower layer of the $\mathrm{AlO}_{x}$ thin film. In general, the surface energy is concerned with the atom arrangement of surface and inside, which means that the measured contact angle

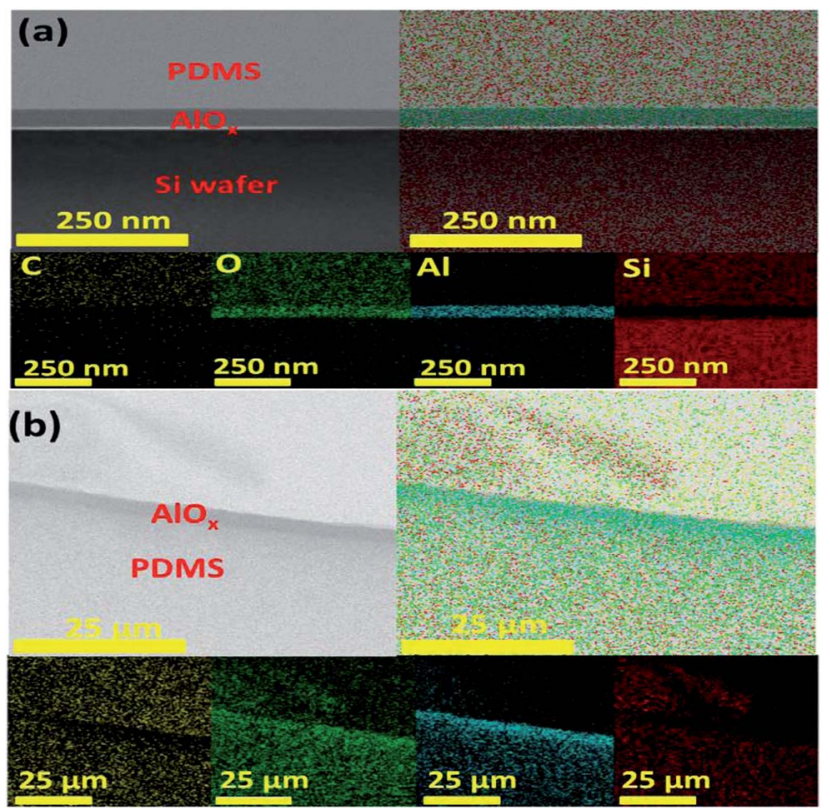

Fig. 5 TEM images and EDS elemental mapping ( $\mathrm{C}, \mathrm{O}$, and $\mathrm{Al}, \mathrm{Si}$ ) of (a) $\mathrm{AlO}_{x} / \mathrm{PDMS}$ and (b) PDMS/AIO 


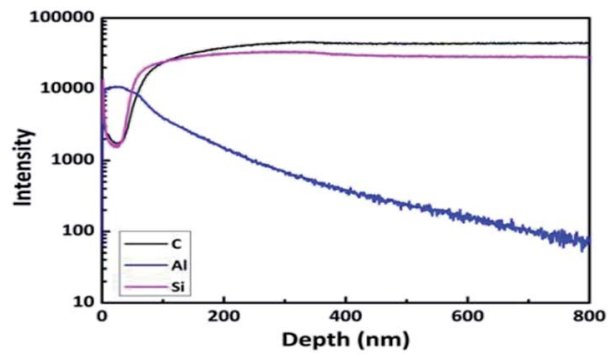

Fig. 6 ToF-SIMS depth profile of Si/PDMS/AIO

(a)

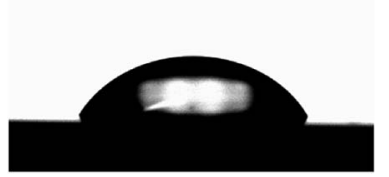

Fig. $7 \mathrm{Si} / \mathrm{PDMS} / \mathrm{AlO}_{x}$ XPS spectra of (a) Al $2 \mathrm{p}$ and (b) O 1s.
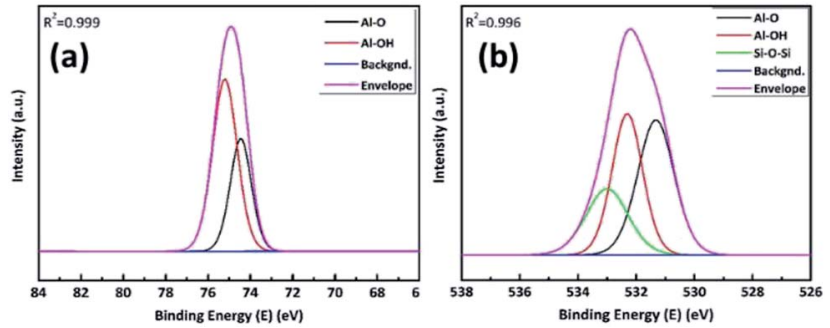

Fig. 8 Contact angles of (a) $\mathrm{Si} / \mathrm{AlO}_{x}$ and (b) $\mathrm{Si} / \mathrm{AlO}_{x} / \mathrm{PDMS}$ using water.

indicates the growth formation of films according to the deposition condition. ${ }^{53}$ Therefore, the difference of surface energy with $\mathrm{PDMS} / \mathrm{AlO}_{x}$ indicated that the surface and internal arrangements of $\mathrm{AlO}_{x}$ changed via deposition on PDMS, which corresponded with TEM-EDS and SIMS results.

\section{Effect of temperature on the WVTR of PDMS/AlO $x$ thin film}

The WVTR value is dependent on the temperature and relative humidity. ${ }^{54,55}$ To examine the relationship between temperature and WVTR values, the $\mathrm{Ca} / \mathrm{AlO}{ }_{x}$ and $\mathrm{Ca} / \mathrm{PDMS} / \mathrm{AlO}_{x}$ samples were stored at three different temperatures: $25{ }^{\circ} \mathrm{C}, 45^{\circ} \mathrm{C}$, and $65^{\circ} \mathrm{C}$. The RH was maintained at $65 \%$. The change in conductance was also monitored. Fig. 9 shows that the lag time increases as the temperature decreases to $25{ }^{\circ} \mathrm{C}$. The result demonstrated that the moisture passage through the film was slow at low temperature. To quantify the moisture barrier property, the WVTR values were determined under each condition (see Table 3). In addition, we determined the activation energy of permeability of the $\mathrm{Ca} / \mathrm{AlO}_{x}$ and $\mathrm{Ca} / \mathrm{PDMS} / \mathrm{AlO}_{x}$ films for permeation as using the following equation..$^{55,56}$

$$
\mathrm{WVTR}=\mathrm{WVTR}_{\mathrm{o}} \times \exp \left(-E_{\mathrm{a}} / R T\right),
$$

where $\mathrm{WVTR}_{\mathrm{o}}$ is a constant dependent on the system, $E_{\mathrm{a}}$ is the activation energy for permeation, and $R$ is the gas constant $\left(8.314 \mathrm{~J} \mathrm{~K}^{-1} \mathrm{~mol}^{-1}\right)$. The activation energy was determined using the linear slope from the graph of ln WVTR versus $1 / R T$. The activation energies of permeability and correlation factors $\left(R^{2}\right)$ of $\mathrm{AlO}_{x}$ and PDMS $/ \mathrm{AlO}_{x}$ were determined to be $30.0 \mathrm{~kJ} \mathrm{~mol}^{-1}\left(R^{2}\right.$ $=0.98)$ and $35.5\left(R^{2}=0.91\right) \mathrm{kJ} \mathrm{mol}^{-1}$, respectively, as shown in Fig. 10. The activation energy of the PDMS/ $\mathrm{AlO}_{x}$ film is greater than that of $\mathrm{AlO}_{x}$ film, which indicates it takes longer time for moisture permeation through the $\mathrm{PDMS} / \mathrm{AlO}_{x}$ film than $\mathrm{AlO}_{x}$ film. ${ }^{57-60}$

\section{PDMS/AlO $x$ encapsulation for PSCs}

Finally, we fabricated the $\left(\mathrm{FAPbI}_{3}\right)_{0.85}\left(\mathrm{MAPbBr}_{3}\right)_{0.15} /$ spiroOMeTAD/Au solar cells, which are encapsulated by two kinds of films: (a) $\mathrm{AlO}_{x}$ and (b) PDMS $/ \mathrm{AlO}_{x}$. The solar cells were subjected to environmental test to examine their stabilities in terms of changes in power conversion efficiency (PCE). Although $\mathrm{AlO}_{x^{-}}$ and encapsulated solar cells suffered over 15\% drop in PCE (see Fig. S2 $\uparrow$ for the degradation), but there were only below $5 \%$ PCE drop for the PDMS $/ \mathrm{AlO}_{x}$-encapsulated devices at $45{ }^{\circ} \mathrm{C}$ in $65 \%$ $\mathrm{RH}$ for $300 \mathrm{~h}$ as shown in Fig. 11. This result shows better longterm stabilities compared to our previous report. ${ }^{61}$

To investigate the main cause of the degradation in our devices, we conducted further experiment at room temperature
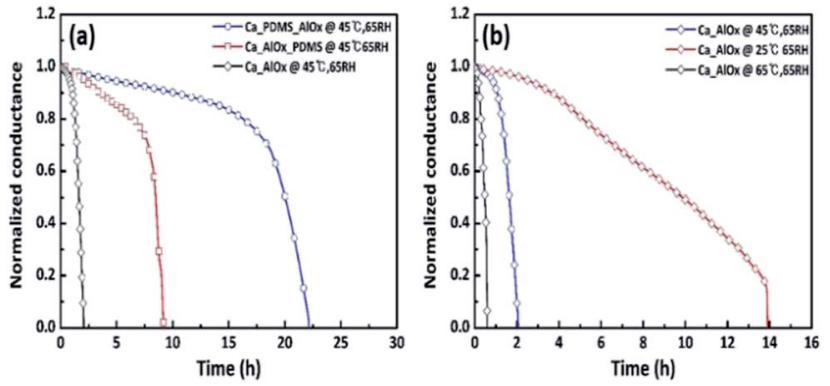

Fig. 9 Ca electrical test results of (a) $\mathrm{PDMS} / \mathrm{AlO}_{x}$ and (b) $\mathrm{AlO}$ x at $65 \%$ $\mathrm{RH}$ in accordance with the temperature.

Table 2 Contact angle and surface tension of $\mathrm{Si} / \mathrm{AlO}{ }_{x}, \mathrm{Si} / \mathrm{AlO}{ }_{x} / \mathrm{PDMS}$ and $\mathrm{Si} / \mathrm{PDMS} / \mathrm{AlO}_{x}$

\begin{tabular}{|c|c|c|c|c|c|}
\hline Sample & DI $\left[^{\circ}\right]$ & $\mathrm{CH}_{2} \mathrm{I}_{2}\left[{ }^{\circ}\right]$ & Polar $\left[\mathrm{mN} \mathrm{m}^{-1}\right]$ & Disp. $\left[\mathrm{mN} \mathrm{m}^{-1}\right]$ & Surface tension $\left[\mathrm{mN} \mathrm{m}^{-1}\right]$ \\
\hline $\mathrm{AlO}_{x}$ & 60.8 & 47.8 & 17.1 & 27.0 & 44.1 \\
\hline $\mathrm{AlO}_{x} / \mathrm{PDMS}$ & 86.8 & 58.8 & 3.9 & 26.1 & 30.0 \\
\hline
\end{tabular}


Table 3 Contact angle and surface tension of $\mathrm{Si} / \mathrm{AlO}_{x}, \mathrm{Si} / \mathrm{AlO}_{x} / \mathrm{PDMS}$ and $\mathrm{Si} / \mathrm{PDMS} / \mathrm{AlO}_{x}$

\begin{tabular}{llll}
\hline Sample & WVTR $\left(\mathrm{g} \mathrm{m}^{-2} \mathrm{~d}^{-1}\right)$ & $\begin{array}{l}\text { Lag time } \\
(\mathrm{h})\end{array}$ & Measurement condition \\
\hline $\mathrm{PDMS} / \mathrm{AlO}_{x}$ & $3.11 \times 10^{-3}$ & 32.29 & $25^{\circ} \mathrm{C}$ and $65 \% \mathrm{RH}$ \\
$\mathrm{PDMS}_{\mathrm{AAlO}}$ & $5.10 \times 10^{-3}$ & 19.71 & $45^{\circ} \mathrm{C}$ and $65 \% \mathrm{RH}$ \\
$\mathrm{PDMS}^{-\mathrm{AlO}_{x}}$ & $2.18 \times 10^{-2}$ & 9.16 & $65^{\circ} \mathrm{C}$ and $65 \% \mathrm{RH}$ \\
$\mathrm{AlO}_{x}$ & $1.35 \times 10^{-2}$ & 6.01 & $25^{\circ} \mathrm{C}$ and $65 \% \mathrm{RH}$ \\
$\mathrm{AlO}_{x}$ & $2.89 \times 10^{-2}$ & 0.86 & $45^{\circ} \mathrm{C}$ and $65 \% \mathrm{RH}$ \\
$\mathrm{AlO}_{x}$ & $6.10 \times 10^{-2}$ & 0.26 & $65^{\circ} \mathrm{C}$ and $65 \% \mathrm{RH}$
\end{tabular}

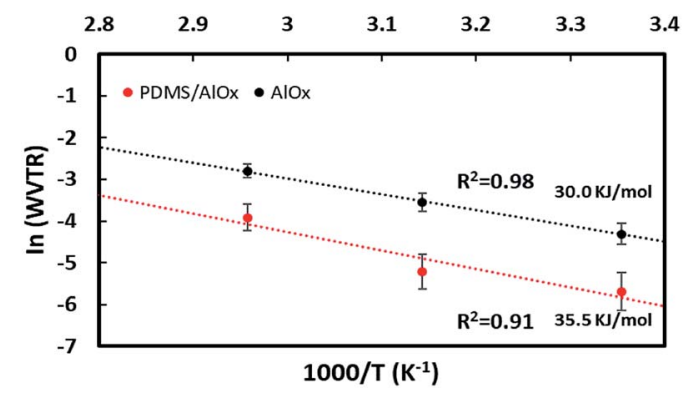

Fig. 10 Plots of the In(WVTR) versus temperatures for $\mathrm{AlO}_{x}$ and PDMS/ $\mathrm{AlO}_{x}$

in $65 \% \mathrm{RH}$ condition with our $\mathrm{PDMS} / \mathrm{AlO}_{x}$-encapsulated devices. As shown in Fig. S5, $\dagger$ the PDMS/AlOx encapsulated PSCs were rarely degraded even though these perovskite cells were exposed in high humidity at room temperature. It should be noted that the perovskite cells with PDMS/AlOx encapsulation layer showed PCE drop about $5 \%$ at $45{ }^{\circ} \mathrm{C}$ in $65 \% \mathrm{RH}$. Therefore, the main degradation mechanism on our devices is likely thermal degradation at spiro-OMeTAD layer as also reported in other literature. ${ }^{61}$ In other words, These results indicate that the $\mathrm{PDMS} / \mathrm{AlO}_{x}$ layer is effective in preventing moisture, but there are still rooms to investigate in the future
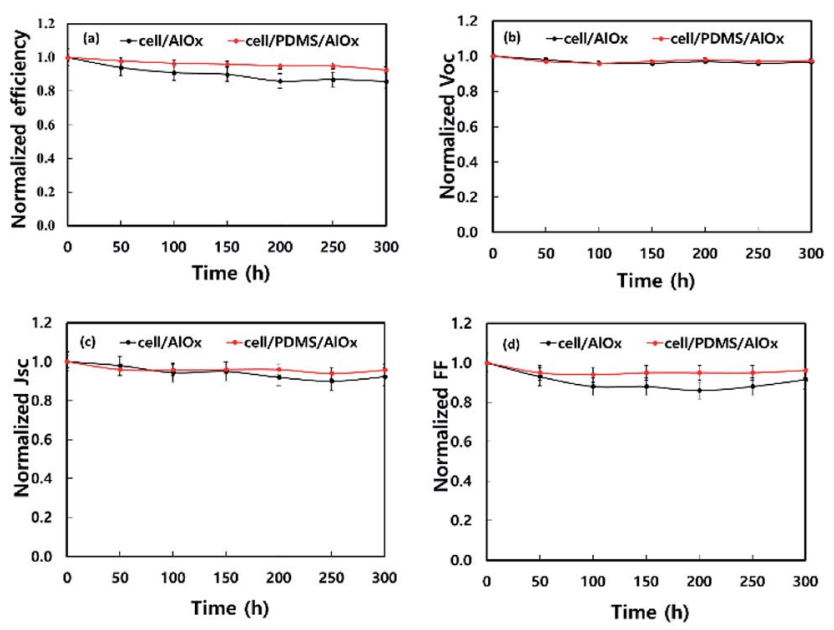

Fig. 11 Evolution of (a) PCE, (b) $V_{\mathrm{OC}}$ (c) $J_{\mathrm{SC}}$ and (d) fill factor of perovskite photovoltaic cells with $\mathrm{AlO}_{x}$ or $\mathrm{PDMS} / \mathrm{AlO}_{x}$ at $45^{\circ} \mathrm{C}$ and $65 \%$ $\mathrm{RH}$ condition. Error bar is standard deviation. for finding a good hole transport layer candidate to ensure longterm stability of perovskite solar cells.

\section{Conclusions}

This study focused on a method to enhance the moisture barrier property and WVTR of the $\mathrm{AlO}_{x}$ thin film using PDMS. In addition, this study demonstrated the use of PDMS/ALD $30 \mathrm{~nm}$ $\mathrm{AlO}_{x}$ layer on top of PSCs as an encapsulant to improve the stability by preventing moisture ingress. We observed that $\mathrm{AlO}_{x}$ filled the vacancy in the PDMS layer when the $\mathrm{AlO}_{x}$ thin films formed on the PDMS layer via ALD. That makes it difficult for moisture to permeate the film, which results in the enhancement of moisture barrier property. We deposited three types of thin films on the Ca film to examine the moisture barrier property. These include (a) $\mathrm{AlO}_{x}$, (b) $\mathrm{AlO}_{x} / \mathrm{PDMS}$, and (c) PDMS/ $\mathrm{AlO}_{x}$. The WVTR values of PDMS/30 nm AlO mized thermal ALD process at a temperature as low as $95^{\circ} \mathrm{C}$ was measured to be $5.1 \times 10^{-3} \mathrm{~g} \mathrm{~m}^{-2} \mathrm{~d}^{-1}$ at $45{ }^{\circ} \mathrm{C}-65 \% \mathrm{RH}$. The activation energies for moisture permeation of the $\mathrm{AlO}_{x}$ and $\mathrm{PDMS} / \mathrm{AlO}_{x}$ films were determined to be $30.0 \mathrm{~kJ} \mathrm{~m}^{-1}$ and $35.5 \mathrm{~kJ} \mathrm{~mol}^{-1}$, respectively. We observed that the PDMS $/ \mathrm{AlO}_{x}$ film was more hydrophobic than the $\mathrm{AlO}_{x}$ film. This is attributed to the low surface tension of PDMS film. Finally, we fabricated the $\left(\mathrm{FAPbI}_{3}\right)_{0.85}\left(\mathrm{MAPbBr}_{3}\right)_{0.15} /$ spiro-OMeTAD/Au perovskite solar cells and encapsulated it by two types of thin films. These include $\mathrm{AlO}_{x}$ and $\mathrm{PDMS} / \mathrm{AlO}_{x}$. The PDMS/AlO ${ }^{-}$ encapsulated solar cells experienced less than $8 \%$ drop in PCE after $300 \mathrm{~h}$ of $45^{\circ} \mathrm{C}-65 \% \mathrm{RH}$. In contrast, the $\mathrm{AlO}_{x}$-encapsulated devices showed over $15 \%$ drop of PCE at $45{ }^{\circ} \mathrm{C}-65 \%$ RH. This is mainly attributed to thermal degradation of spiro-OMeTAD. With further development in the moisture barrier property of the $\mathrm{AlO}_{x}$ film by employing the PDMS layer, we propose that the ALD process is an excellent approach to encapsulate perovskite solar cells.

\section{Experimental section}

\section{Experimental apparatus}

In this experiment, we designed an ALD system that is connected to a glove box. A thermal evaporator was installed inside the glove box, which can handle calcium (Ca) in a nitrogen condition. We formed the Ca layer on a glass using thermal evaporator, and then coated the PDMS on the Ca layer using a spin coater (Ca/PDMS). After curing the PDMS, the samples were placed in the ALD chamber to deposit $\mathrm{AlO}_{x}$. The whole process was performed in nitrogen environment. Each condition of this experiment is explained in detail in the next section.

\section{Ca cell fabrication and characterization}

Ca cell fabrication. The $300 \mathrm{~nm}$ Ca film was formed on a glass substrate $(2.5 \mathrm{~cm} \times 2.5 \mathrm{~cm})$ using thermal evaporator. After Ca deposition, the $200 \mathrm{~nm} \mathrm{Al} \mathrm{electrode} \mathrm{was} \mathrm{deposited} \mathrm{onto}$ the glass via evaporator (Fig. 1a). The next step is to encapsulate the Ca samples. For this, the Ca samples were divided into three groups, as shown in Fig. 1. These include (a) $\mathrm{AlO}_{x}$ deposition 
$\left(\mathrm{Ca} / \mathrm{AlO}_{x}\right)$, (b) $\mathrm{AlO}_{x}$ deposition and then PDMS coating $\left(\mathrm{Ca} / \mathrm{AlO}_{x} /\right.$ PDMS), and (c) PDMS coating and then $\mathrm{AlO}_{x}$ deposition $(\mathrm{Ca} /$ PDMS/AlO ${ }_{x}$ ). PDMS (Sylgard 184, Sigma Aldrich) was used in this study. The silicone elastomer was mixed with a curing agent in a $10: 1$ ratio by weight. The PDMS was coated at $1000 \mathrm{rpm}$ for $30 \mathrm{~s}$. Further, it was annealed at $95{ }^{\circ} \mathrm{C}$ for $1 \mathrm{~h}$. The thickness of PDMS was measured to be about $55 \mu \mathrm{m}$ (see Fig. S3†).

ALD deposition condition. We employed a thermal ALD process (model: IH-10, ITECHU, South Korea) in this study. The ALD procedure consists of four steps: (1) the TMA precursor was pulsed into reaction chamber, (2) Ar gas was purged to clean the reaction chamber, (3) $\mathrm{H}_{2} \mathrm{O}$ reactant was pulsed into reaction, and (4) excess reactant was removed from reaction chamber by Ar purging. To make sure of deposition thickness of $\mathrm{AlO}_{x}$, we investigated the effect of two factors on the deposition rate: (1) TMA pulse time and (2) water pulse time. The test conditions are summarized in Table $\mathrm{S} 2 . \dagger$ Further, we examined the relationship between ALD cycles and $\mathrm{AlO}_{x}$ thickness.

Characterization of Ca cell. The Ca cells were placed in three different temperature-humidity conditions: (a) $25{ }^{\circ} \mathrm{C}-65 \% \mathrm{RH}$, (b) $45{ }^{\circ} \mathrm{C}-65 \% \mathrm{RH}$, and (c) $65{ }^{\circ} \mathrm{C}-65 \% \mathrm{RH}$. The change in conductance $(G)$ was measured in each condition (Keithley 2400 multimeter). Using the change in $G$, we determined the WVTR values using the equation stated in ref. 62 .

$$
\mathrm{WVTR}=-2\left(\frac{M_{\mathrm{H}_{2} \mathrm{O}}}{M_{\mathrm{Ca}}}\right) \rho_{\mathrm{Ca}} \sigma\left(\frac{\mathrm{d}(G)}{\mathrm{d}(t)}\right)\left(\frac{A_{\mathrm{Ca}}}{A}\right),
$$

where 2 is the molar equivalent of Ca corrosion reaction, $M_{\mathrm{H}_{2} \mathrm{O}}$ $\left(18 \mathrm{~g} \mathrm{~mol}^{-1}\right)$ and $M_{\mathrm{Ca}}\left(40.1 \mathrm{~g} \mathrm{~mol}^{-1}\right)$ are the molecular weights of water and $\mathrm{Ca}$, respectively, $\rho_{\mathrm{Ca}}\left(1.55 \mathrm{~g} \mathrm{~cm}^{-3}\right)$ is the density of $\mathrm{Ca}$, $\sigma\left(3.4 \times 10^{-8} \Omega \mathrm{m}\right)$ is the resistivity of $\mathrm{Ca}, \frac{d(G)}{\mathrm{d}(t)}$ is the rate of conductance $(G)$ change, $A_{\mathrm{Ca}}$ is the area of deposited $\mathrm{Ca}$, and $A$ is the barrier film area on $\mathrm{Ca}$.

\section{Perovskite solar cell fabrication and characterization}

\section{Materials}

(1) Synthesis of perovskite absorption materials. (a) To synthesize $\mathrm{HC}\left(\mathrm{NH}_{2}\right)_{2} \mathrm{I}, 15 \mathrm{~g}$ formamidine acetate and $30 \mathrm{ml} \mathrm{HI} \mathrm{(57} \mathrm{wt \%}$ in water) were mixed in $100 \mathrm{ml}$ ethanol at $0{ }^{\circ} \mathrm{C}$ for $2 \mathrm{~h}$. After reacting the solution of $\mathrm{HC}\left(\mathrm{NH}_{2}\right)_{2} \mathrm{I}$ was dried with rotary evaporator at $50{ }^{\circ} \mathrm{C}$ for $1 \mathrm{~h}$ The white crystals were obtained following recrystallization from ethanol and washing with diethyl ether. (b) To obtain $\mathrm{CH}_{3} \mathrm{NH}_{3} \mathrm{Br}$, the mixture solution of $11 \mathrm{ml}$ methylamine (33 wt\% in water) and $10 \mathrm{ml} \mathrm{HBr}$ (48 wt\% in water) were stirred in $100 \mathrm{ml}$ ethanol at $0{ }^{\circ} \mathrm{C}$ for $2 \mathrm{~h}$.

(2) Preparation of perovskite absorption solutions. To prepare 1.2 $\mathrm{M} \mathrm{HC}\left(\mathrm{NH}_{2}\right)_{2} \mathrm{PbI}_{3}$ solution, $\mathrm{HC}\left(\mathrm{NH}_{2}\right)_{2} \mathrm{I}$ and $\mathrm{PbI}_{2}$ were dissolved at room temperature in dimethylformamide (DMF) : dimethyl sulfoxide mixed solvent ( $1: 0.25(\mathrm{v} / \mathrm{v}))$. To fabrication of $\mathrm{CH}_{3} \mathrm{NH}_{3} \mathrm{Br}$ solution, the sequence of work was the same manner as described above. After preparing of base solution, $0.85 \mathrm{ml}$ of $\mathrm{HC}\left(\mathrm{NH}_{2}\right)_{2} \mathrm{PbI}_{3}$ and $0.15 \mathrm{ml}$ of $\mathrm{CH}_{3} \mathrm{NH}_{3} \mathrm{Br}_{3}$ solution were mixed to obtain $\left(\mathrm{HC}\left(\mathrm{NH}_{2}\right)_{2} \mathrm{PbI}_{3}\right)_{0.85}\left(\mathrm{CH}_{3} \mathrm{NH}_{3} \mathrm{PbBr}_{3}\right)_{0.15}$ mixed solution and extra $\mathrm{PbI}_{2}\left(5 \mathrm{~mol} \%\right.$ to $\left.\mathrm{HC}\left(\mathrm{NH}_{2}\right)_{2} \mathrm{PbI}_{3}\right)$ were added heating at $60{ }^{\circ} \mathrm{C}$ for $30 \mathrm{~min}$.
Fabrication of perovskite solar cells. The used photovoltaics devices were fabricated with the following structures, FTO/c$\mathrm{TiO}_{2} / m-\mathrm{TiO}_{2} /$ perovskite/sprio-OMeTAD/Au. The procedure for cleaning the substrate included sonication and rinsing in distilled water, acetone, and isopropyl alcohol. About $50 \mathrm{~nm}$ of compact $\mathrm{TiO}_{2}\left(\mathrm{c}-\mathrm{TiO}_{2}\right)$ was deposited by spray pyrolysis with $20 \mathrm{mM}$ titanium diiopropoxide bis(acetylacetonate) solution at $450{ }^{\circ} \mathrm{C}$ on FTO substrate. $150 \mathrm{mg} \mathrm{ml}^{-1}$ of mesoporous $\mathrm{TiO}_{2}(\mathrm{~m}$ $\mathrm{TiO}_{2}$, Dysol $30 \mathrm{NR}-\mathrm{D}$ ) in ethanol was coated at $5000 \mathrm{rpm}$ (acceleration of $2000 \mathrm{rpm} \mathrm{s}^{-1}$ ) for $10 \mathrm{~s}$ and heated $100{ }^{\circ} \mathrm{C}$ for $10 \mathrm{~min}$. After process, the substrate was sintered at $500{ }^{\circ} \mathrm{C}$ for $30 \mathrm{~min}$. The mixed perovskite solution described above was spin-coated at $2000 \mathrm{rpm}$ (acceleration of $200 \mathrm{rpm} \mathrm{s}^{-1}$ ) for $10 \mathrm{~s}$ followed by $6000 \mathrm{rpm}$ (acceleration of $2000 \mathrm{rpm} \mathrm{s}^{-1}$ ) for $30 \mathrm{~s}$. During the last $20 \mathrm{~s}$ of the second coating steps, the cholorobenzene (CB), which works as anti-solvent, dropped. The perovskite film was heated at $100{ }^{\circ} \mathrm{C}$ for $20 \mathrm{~min}$. A solution including $41.6 \mathrm{mg}$ of spiro-OMeTAD, $7.5 \mu \mathrm{L}$ of $500 \mathrm{mg} \mathrm{ml}^{-1}$ lithium bis(trfluoromethylsulphonyl)-imide (Li-TFSI) in acetonitrile $(\mathrm{ACN})$ and 16. $9 \mu \mathrm{L}$ of 4-tert-butylpyridine $(t \mathrm{BP})$ in $0.5 \mathrm{ml}$ of $\mathrm{CB}$ was dropped and coated on the perovskite layer at $2000 \mathrm{rpm}$ (acceleration of $1200 \mathrm{rpm} \mathrm{s}^{-1}$ ) for $20 \mathrm{~s} .100 \mathrm{~nm}$ of $\mathrm{Au}$ contacts were formed sequentially by vacuum deposition.

Characterization and stability test of PSCs. The film thickness of $\mathrm{AlO}_{x}$ was measured using a spectroscopic ellipsometer (model: Elli-SE). To confirm the crystallinity of the film, the determined X-ray diffraction (XRD) patterns were measured using XRD-6100 (SHIMADZU, JAPAN) with a $\mathrm{Cu} \mathrm{K} \alpha$ radiation source $(\lambda=0.1541 \mathrm{~nm})$ at $30 \mathrm{kV}$ and $30 \mathrm{~mA}$. X-ray photoelectron spectroscopy (XPS) was performed using (Thetaprobe XPS, Thermo-Fisher Scientific) with $\mathrm{Al} \mathrm{K} \alpha$ source at $15 \mathrm{kV}$ to analyze the chemical bonding and composition of the film. The measured XPS data was calibrated using $C$ 1s peak with $284.6 \mathrm{eV}$. The contact angle and surface tension values were measured with Phoenix 300 from SEO Co., Ltd., using DI and diiodomethane. The surface energy was determined by the Owen-Wendt equation using two measuring liquids. ${ }^{63}$

$$
\gamma_{\mathrm{L}}(1+\cos \theta)=2\left(\gamma_{\mathrm{S}}^{\mathrm{d}} \gamma_{\mathrm{L}}^{\mathrm{d}}\right)^{1 / 2}+\left(\gamma_{\mathrm{S}}^{\mathrm{p}} \gamma_{\mathrm{L}}^{\mathrm{p}}\right)^{1 / 2}
$$

where $\theta$ is the measured contact angle of the measuring liquid on the surface, the dispersion and polarity components of water are $\gamma_{\mathrm{L}}^{\mathrm{d}}=22.85$ dyn $\mathrm{cm}^{-1}$ and $\gamma_{\mathrm{L}}^{\mathrm{p}}=50.3 \mathrm{dyn}_{\mathrm{cm}}^{-1}$, respectively, and the components of diiodoemethane are $\gamma_{\mathrm{L}}^{\mathrm{d}}=48.5 \mathrm{dyn} \mathrm{\textrm {cm } ^ { - 1 }}$ and $\gamma_{\mathrm{L}}^{\mathrm{p}}=2.3$ dyn $\mathrm{cm}^{-1}$

To perform TEM, samples mounted on $\mathrm{Cu}$ girds were fabricated using a focused ion beam. The prepared sample was measured with JEM-2100F (JEOL Ltd) operating at $200 \mathrm{kV}$ equipped with EDS (TEM 250, Oxford Instruments). The current density-voltage measurements were obtained by the solar cell testing system (LAB 200, McScience, Korea) including simulated solar light (AM 1.5G) with an intensity of $100 \mathrm{~mW} \mathrm{~cm}^{-2}$ using the K3000 model (McScience) and recorder using the ADCMT 6244 source measure unit. After masking with $0.075 \mathrm{~cm}^{2}$ aperture, the solar cells were measured at a scan rate of $1.2 \mathrm{~V} \mathrm{~s}^{-1}$. All the results were obtained under ambient conditions. The illumination intensity was calibrated using a standard Si reference 
cell (K801S-K067, McScience, Korea). The perovskite solar cell stability test was conducted at $45{ }^{\circ} \mathrm{C}-65 \% \mathrm{RH}$ (TH401HA, ETAC, Japan).

\section{Conflicts of interest}

There are no conflicts to declare.

\section{Acknowledgements}

This research was supported by the Technology Development Program to Solve Climate Changes of the National Research Foundation (NRF) funded by the Ministry of Science and ICT (No. 2017M1A2A2048905), and the New \& Renewable Energy of the Korea Institute of Energy Technology Evaluation and Planning (KETEP) grant funded by the Ministry of Trade, Industry and Energy (MOTIE) (No. 20173010012970).

\section{Notes and references}

1 J. H. Noh, S. H. Im, J. H. Heo, T. N. Mandal and S. I. Seok, Nano Lett., 2013, 13, 1764-1769.

2 J. M. Frost, K. T. Butler, F. Brivio, C. H. Hendon, M. Van Schilfgaarde and A. Walsh, Nano Lett., 2014, 14, 2584-2590.

3 J. Cao, J. Yin, S. Yuan, Y. Zhao, J. Li and N. Zheng, Nanoscale, 2015, 7, 9443-9447.

4 T. Leijtens, G. E. Eperon, N. K. Noel, S. N. Habisreutinger, A. Petrozza and H. J. Snaith, Adv. Energy Mater., 2015, 5, 1500963.

5 Y. Han, S. Meyer, Y. Dkhissi, K. Weber, J. M. Pringle, U. Bach, L. Spiccia and Y.-B. Cheng, J. Mater. Chem. A, 2015, 3, 81398147.

6 H. Kim, K.-G. Lim and T.-W. Lee, Energy Environ. Sci., 2016, 9, 12-30.

7 X. Dong, X. Fang, M. H. Lv, B. C. Lin, S. Zhang, J. N. Ding and N. Y. Yuan, J. Mater. Chem. A, 2015, 3, 5360-5367.

8 L. Shi, T. L. Young, J. Kim, Y. Sheng, L. Wang, Y. F. Chen, Z. Q. Feng, M. J. Keevers, X. J. Hao, P. J. Verlinden, M. A. Green and A. W. Y. Ho-Baillie, ACS Appl. Mater. Interfaces, 2017, 9, 25073-25081.

9 S. N. Habisreutinger, T. Leijtens, G. E. Eperon, S. D. Stranks, R. J. Nicholas and H. J. Snaith, Nano Lett., 2014, 14, 55615568.

10 A. Y. Mei, X. Li, L. F. Liu, Z. L. Ku, T. F. Liu, Y. G. Rong, M. Xu, M. Hu, J. Z. Chen, Y. Yang, M. Gratzel and H. W. Han, Science, 2014, 345, 295-298.

11 I. Hwang, I. Jeong, J. Lee, M. J. Ko and K. Yong, ACS Appl. Mater. Interfaces, 2015, 7, 17330-17336.

12 H. C. Weerasinghe, Y. Dkhissi, A. D. Scully, R. A. Caruso and Y.-B. Cheng, Nano Energy, 2015, 18, 118-125.

13 Q. Dong, F. Liu, M. K. Wong, H. W. Tam, A. B. Djurišić, A. Ng, C. Surya, W. K. Chan and A. M. C. Ng, ChemSusChem, 2016, 9, 2597-2603.

14 F. Matteocci, L. Cinà, E. Lamanna, S. Cacovich, G. Divitini, P. A. Midgley, C. Ducati and A. Di Carlo, Nano Energy, 2016, 30, 162-172.
15 L. Wang, C. Ruan, M. Li, J. Zou, H. Tao, J. Peng and M. Xu, J. Mater. Chem. C, 2017, 5, 4017-4024.

16 T. Nam, Y. J. Park, H. Lee, I.-K. Oh, J.-H. Ahn, S. M. Cho, H. Kim and H.-B.-R. Lee, Carbon, 2017, 116, 553-561.

17 E. Y. Choi, J. Kim, S. Lim, E. Han, A. W. Ho-Baillie and N. Park, Sol. Energy Mater. Sol. Cells, 2018, 188, 37-45.

18 M.-H. Park, J.-Y. Kim, T.-H. Han, T.-S. Kim, H. Kim and T.-W. Lee, Adv. Mater., 2015, 27, 4308-4314.

19 H.-K. Seo, M.-H. Park, Y.-H. Kim, S.-J. Kwon, S.-H. Jeong and T.-W. Lee, ACS Appl. Mater. Interfaces, 2016, 8, 14725-14731.

20 Z. Liu, B. Sun, T. Shi, Z. Tang and G. Liao, J. Mater. Chem. A, 2016, 4, 10700-10709.

21 X. Ling, C. Ser Choong, C. S. Premachandran, D. Pinjala and M. K. Iyer, 7th Electronic Packaging Technology Conference (EPTC), 2005, vol. 1, p. 5.

22 M. C. Bélanger and Y. Marois, J. Biomed. Mater. Res., 2001, 58, 467-477.

23 S. H. Jeong, S. Zhang, K. Hjort, J. Hilborn and Z. Wu, Adv. Mater., 2016, 28, 5830-5836.

24 X. Liu, Y. Xu, K. Ben, Z. Chen, Y. Wang and Z. Guan, Appl. Surf. Sci., 2015, 339, 94-101.

25 M. Tovar, T. Weber, S. Hengoju, A. Lovera, A.-S. Munser, O. Shvydkiv and M. Roth, Biomicrofluidics, 2018, 12, 024115.

26 J. Wang, S. Wang, P. Zhang and Y. Li, 18th International Conference on Electronic Packaging Technology (ICEPT), 2017, vol. 1, pp. 1051-1055.

27 C. Wu, T. G. Lin, Z. Zhan, Y. Li, S. C. H. Tung, W. C. Tang and W. J. Li, Microsyst. Nanoeng., 2017, 3, 16084.

28 S. H. Kim, J.-H. Moon, J. H. Kim, S. M. Jeong and S.-H. Lee, Biomed. Eng. Lett., 2011, 1, 199.

29 S. Sonney, N. Shek and J. M. Moran-Mirabal, Biomicrofluidics, 2015, 9, 026501.

30 S. Martin and B. Bhushan, J. Colloid Interface Sci., 2017, 488, 118-126.

31 J. Niinistö, Atomic Layer Deposition of High-k Dielectrics from Novel Cyclopentadienyl-Type Precursors, Doctor's dissertation, Helsinki University of Technology, Otaniemi, Helsinki, 2006.

32 W. Lu, Y. Iwasa, Y. Ou, D. Jinno, S. Kamiyama, P. M. Petersen and H. Ou, RSC Adv., 2017, 7, 8090-8097.

33 J. Haeberle, K. Henkel, H. Gargouri, F. Naumann, B. Gruska, M. Arens, M. Tallarida and D. Schmeißer, Beilstein J. Nanotechnol., 2013, 4, 732-742.

34 T. Van Khai, H. G. Na, D. S. Kwak, Y. J. Kwon, H. Ham, K. B. Shim and H. W. Kim, J. Mater. Chem., 2012, 22, 17992-18003.

35 J. G. Lee, H. G. Kim and S. S. Kim, Thin Solid Films, 2015, 577, 143-148.

36 A. Bulusu, A. Singh, C. Y. Wang, A. Dindar, C. FuentesHernandez, H. Kim, D. Cullen, B. Kippelen and S. Graham, J. Appl. Phys., 2015, 118, 085501.

37 K. H. Yoon, H. S. Kim, K. S. Han, S. H. Kim, Y.-E. K. Lee, N. K. Shrestha, S. Y. Song and M. M. Sung, ACS Appl. Mater. Interfaces, 2017, 9, 5399-5408.

38 T. Bülow, H. Gargouri, M. Siebert, R. Rudolph, H.-H. Johannes and W. Kowalsky, Nanoscale Res. Lett., 2014, 9, 223. 
39 L. Lee, K. H. Yoon, J. W. Jung, H. R. Yoon, H. Kim, S. H. Kim, S. Y. Song, K. S. Park and M. M. Sung, Nano Lett., 2018, 18, 5461-5466.

40 J. C. Spagnola, B. Gong, S. A. Arvidson, J. S. Jur, S. A. Khan and G. N. Parsons, J. Mater. Chem., 2010, 20, 4213-4222.

41 J. M. Mohr and D. R. Paul, J. Appl. Polym. Sci., 1991, 42, 17111720.

42 V. Compañ, A. Andrio, M. L. López, C. Alvarez and E. Riande, Macromolecules, 1997, 30, 3317-3322.

43 N. Bosq, N. Guigo, J. Persello and N. Sbirrazzuoli, Phys. Chem. Chem. Phys., 2014, 16, 7830-7840.

44 A. Bulusu, S. Graham, H. Bahre, H. Behm, M. Böke, R. Dahlmann, C. Hopmann and J. Winter, Adv. Eng. Mater., 2015, 17, 1057-1067.

45 M. A. Mendez and V. A. Szalai, Nanoscale Res. Lett., 2013, 8, 210.

46 D. N. Goldstein, J. A. McCormick and S. M. George, J. Phys. Chem. C, 2008, 112, 19530-19539.

47 S. Armyanov, N. E. Stankova, P. A. Atanasov, E. Valova, K. Kolev, J. Georgieva, O. Steenhaut, K. Baert and A. Hubin, Nucl. Instrum. Methods Phys. Res., Sect. B, 2015, 360, 30-35.

48 S. R. Saptarshi, A. Duschl and A. L. Lopata, J. Nanobiotechnol., 2013, 11, 26.

49 G. N. Parsons, S. E. Atanasov, E. C. Dandley, C. K. Devine, B. Gong, J. S. Jur, K. Lee, C. J. Oldham, Q. Peng, J. C. Spagnola and P. S. Williams, Coord. Chem. Rev., 2013, 257, 3323-3331.

50 C. A. Wilson, R. K. Grubbs and S. M. George, Chem. Mater., 2005, 17, 5625-5634.
51 J. Wang, T. Pan, J. Zhang, X. Xu, Q. Yin, J. Han and M. Wei, RSC Adv., 2018, 8, 21651-21657.

52 Z. Huang, F. Wang and J. Li, 11th International Conference on the Properties and Applications of Dielectric Materials (ICPADM), 2015, vol. 1, pp. 293-296.

53 H.-Y. Li, Y.-F. Liu, Y. Duan, Y.-Q. Yang and Y.-N. Lu, Materials, 2015, 8, 600.

54 T. Ohishi, Y. Yamazaki and T. Nabatame, Frontiers in Nanoscience and Nanotechnology, 2016, 2(4), 149-154.

55 S. Park, L. H. Kim, Y. J. Jeong, K. Kim, M. Park, Y. Baek, T. K. An, S. Nam, J. Jang and C. E. Park, Org. Electron., 2016, 36, 133-139.

56 W. M. Yun, J. Jang, S. Nam, Y. J. Jeong, L. H. Kim, S. Park, S. J. Seo and C. E. Park, J. Mater. Chem., 2012, 22, 2539525401.

57 B. M. Henry, A. G. Erlat, A. McGuigan, C. R. M. Grovenor, G. A. D. Briggs, Y. Tsukahara, T. Miyamoto, N. Noguchi and T. Niijima, Thin Solid Films, 2001, 382, 194-201.

58 Y. Y. Tomoji Ohishi, Mater. Sci. Appl., 2017, 1-14.

59 T. Ohishi and K. Yanagida, Frontiers in Nanoscience and Nanotechnology, 2016, 2(5), 173-178.

60 S.-H. Schulze, C. Ehrich, R. Meitzner and M. Pander, Prog. Photovoltaics, 2017, 25, 1051-1058.

61 J. Kim, N. Park, J. S. Yun, S. Huang, M. A. Green and A. W. Y. Ho-Baillie, Sol. Energy Mater. Sol. Cells, 2017, 162, 41-46.

62 R. Paetzold, A. Winnacker, D. Henseler, V. Cesari and K. Heuser, Rev. Sci. Instrum., 2003, 74, 5147-5150.

63 D. Hong, K. Bae, S.-P. Hong, J. H. Park, I. S. Choi and W. K. Cho, Chem. Commun., 2014, 50, 11649-11652. 